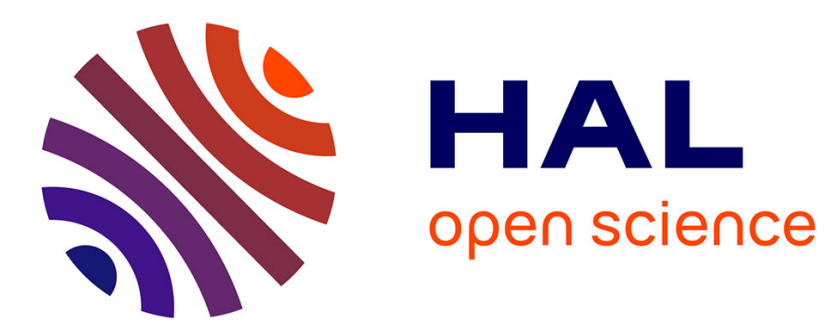

\title{
Mobbing and its determinants: the case of Spain
}

M. Angeles Carnero, Blanca Martínez, Rocío Sánchez-Mangas

\section{To cite this version:}

M. Angeles Carnero, Blanca Martínez, Rocío Sánchez-Mangas. Mobbing and its determinants: the case of Spain. Applied Economics, 2008, 42 (29), pp.3777. 10.1080/00036840802360112 . hal00582177

\section{HAL Id: hal-00582177 \\ https://hal.science/hal-00582177}

Submitted on 1 Apr 2011

HAL is a multi-disciplinary open access archive for the deposit and dissemination of scientific research documents, whether they are published or not. The documents may come from teaching and research institutions in France or abroad, or from public or private research centers.
L'archive ouverte pluridisciplinaire HAL, est destinée au dépôt et à la diffusion de documents scientifiques de niveau recherche, publiés ou non, émanant des établissements d'enseignement et de recherche français ou étrangers, des laboratoires publics ou privés. 


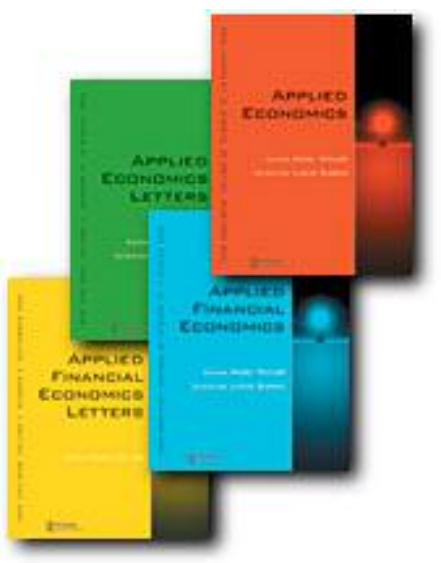

Mobbing and its determinants: the case of Spain

\begin{tabular}{|r|l|}
\hline Journal: & Applied Economics \\
\hline Manuscript ID: & APE-06-0638 \\
\hline Journal Selection: & Applied Economics \\
\hline JEL Code: & $\begin{array}{l}\text { C20 - General < C2 - Econometric Methods: Single Equation Models } \\
<\text { C - Mathematical and Quantitative Methods, J28 - Safety; } \\
\text { Accidents; Industrial Health; Job Satisfaction; Public Policy < J2 - } \\
\text { Time Allocation, Work Behavior, and Employment } \\
\text { Determination/Creation < J - Labor and Demographic Economics }\end{array}$ \\
\hline Keywords: & Bullying at workplace, Moral harassment \\
\hline \multicolumn{2}{|l}{} \\
\hline
\end{tabular}

\section{5cholaronE" Manuscript Central}




\title{
Mobbing and its determinants: the case of Spain
}

\begin{abstract}
The objective of this paper is to analyze empirically the problem of mobbing in Spain. Based on the fifth Spanish survey on working conditions, we find that during 2003, around $5 \%$ of workers declared being mobbed at their workplace. Some personal, job characteristics and working conditions are found to be significant at explaining the probability of being a mobbing victim. Finally, we find differences in the variables affecting such probability depending on the victim's gender.
\end{abstract}

JEL Classification:C20, J28

Keywords:Bullying at workplace, Moral harassment. 


\section{Introduction}

The term Mobbing was popularized during the 80's by H. Leymann, who called mobbing a kind of long-term hostile behavior detected in employees at workplaces. Using Leymann's definition ${ }^{1}$, "psychological terror or mobbing in working life involves hostile and unethical communication which is directed in a systematic manner by one or more individuals, mainly toward one individual, who, due to mobbing, is pushed into a helpless and defenseless position and held there by means of continuing mobbing activities. These actions occur on a frequent basis (at least once a week) and over a long period of time (at least six months' duration). Because of the high frequency and long duration of hostile behavior, this maltreatment results in considerable mental, psychosomatic and social misery". Leymann considered 45 activities representative of mobbing which are contained in the LIPT -Leymann Inventory of Psychological Terrorization- questionnaire; see Appendix A. These activities include verbal aggressions, rumors, humiliations and so on. Three types of mobbing can be considered depending on the link between victims and aggressors: horizontal, up-down and down-up mobbing. Updown mobbing occurs when a superior harasses one of his subordinates. Down-up mobbing occurs when a worker or a group or workers harasses his/their superior. When mobbing occurs between co-workers at the same hierarchical level it is called horizontal mobbing.

The identification of mobbing is not a trivial task since hostile activities at work are sometimes of quite normal interactive behaviors. However, it is when such activities are used frequently and over a long period of time in order to harass, when they turn into dangerous communicative weapons. It is their systematic use what starts the mobbing process.

The objective of mobbing ${ }^{2}$, following the Technical Prevention Note (NTP476) of the Instituto Nacional de Seguridad e Higiene en el Trabajo, is to destroy the social net of the victim, to disrupt his job, to destroy his reputation and to achieve that the victim quits his job. So, mobbing could be a way of getting rid of the worker without paying any compensation. On the other hand, some authors, e.g. Lewis (2006), see mobbing as "learned behavior" within the workplace, rather than any predominantly psychological deficit within perpetrators and targets.

There are recent studies for most European countries which quantify the importance of mobbing, although the percentages of mobbing victims range quite a lot. For example, Hubert et. al (2001) find that 1\% of workers in the financial

\footnotetext{
${ }^{1}$ See, for example, The Mobbing Encyclopedia at http://www.leymann.se.

${ }^{2}$ Moral harassment, victimization or psychological terror are other terms used in the literature to describe this hostile behavior. Bullying is the term used in English-speaking countries.
} 
sector in Holland suffer from mobbing. Cowie et. al (2000) find that $38 \%$ of international institutions workers are mobbed in England. However, since the methodology used and the sample of workers are different in the previous works, such percentages are not really comparable.

The Informe Cisneros is the first and most complete research about mobbing developed in Spain. The Barómetro Cisneros elaborated by Piñuel y Zabala and Oñate (2002), was carried out in 2001 and 2002. For the 2001 survey, around 1000 workers from Madrid and Guadalajara were interviewed. In order to avoid subjectivity, the questionnaire includes a first part in which the workers do not know that the behaviors cited in the questionnaire describe mobbing activities. Then, the workers are asked about the scale, intensity, causes and reactions of the mobbing experience. For the 2002 survey, a total of 2410 workers from an industrial area near Madrid were interviewed. The 2002 survey includes questions related to the physical and psychological problems derived from mobbing.

Understanding and quantifying the process of mobbing is important because of its socio-economic consequences. In fact, not only the victim is involved in this problem but also the firm and the society. Vega and Comer (2005) argue that mobbing activities, often accepted by the organization, can create an environment of psychological threat that diminishes productivity and inhibits individual and group commitment. Links have also been found between mobbing and mental and physical health problems. Piñuel y Zabala and Oñate (2002) found that around $16 \%$ of workers reported being subjected to moral harassment or mobbing, and over half of the mobbing victims answered that mobbing affects their physical and mental health. Finally there are some attempts to measure the economic consequences for the society. Pastrana (2002), focussing on one of the possible mobbing outcomes, disability, estimates the cost of mobbing in Spain. By analyzing a sample of 6500 temporary disability cases, he found that mobbing victims account for $1.71 \%$ of the temporary disability cases, which implies that, during the year 2002, 52 million Euros were lost in work compensation as a consequence of mobbing behaviors in Spain.

The objective of this paper is twofold. First, we quantify the importance of mobbing in Spain using the fifth Spanish survey on working conditions, VENCT (2003), which was conducted by the Instituto Nacional de Seguridad e Higiene en el Trabajo. It includes, for the first time, some questions related to psychological factors and violence at work. Secondly, we study which are the determinants of mobbing behaviors at the workplace and analyze which variables are significant at explaining the probability of being a mobbing victim. The causes of mobbing could be numerous and arise from the organization, the perpetrator or even from 
the victim. Hirigoyen (2001) shows that the personality of the victims could explain the mobbing processes. Leymann (1996) identified two main sources as the cause of mobbing: work organization and poor conflict management. We will focus on Leymann's study and investigate if work organization and working conditions can explain the probability of being mobbed. Poor conflict management should be also important but unfortunately our data do not allow us to test this hypothesis.

The paper is organized as follows. Section 2 describes the data analyzed and reveals some empirical facts of mobbing in Spain. In section 3 several variables possibly related to the problem are considered and their impact on the probability of being a mobbing victim is estimated. Finally, section 4 contains the conclusions and further lines of research.

\section{Data description}

We have used data from the fifth Spanish survey on working conditions, VENCT (2003), which was conducted by the Instituto Nacional de Seguridad e Higiene en el Trabajo. It covers 5236 workers and provides detailed information on working conditions, including, for the first time, some questions related to psychological factors and violence at work. The questionnaire also includes questions on work and job characteristics as well as socio-demographic variables.

With the information available we can identify mobbing victims, following Leymann's definition, by focusing on the two questions related to violence behavior at work:

P.79. During the last 12 months, have you been subjected at work to: physical violence from people form your workplace, from other people or unwanted sexual attention?

P.80. During the last 12 months, have you and how often, while working, been silenced, ignored, isolated, humiliated or ridiculed in connection with your work or personal life, suffering from verbal and written threats, or other similar behaviors?

P.80 is a multiple choice question. The possible answers are: yes, daily; yes, at least once per week; yes, several times per month; yes, several times per year; no. P.79 is a yes/no question and does not give information about the frequency of the violent behavior. Notice also that we do not know the duration of these hostile behaviors. Consequently, Leymann's definition can not be applied literally.

With the information we have, we select the mobbing victims as those workers 
answering yes to $P .79^{3}$ plus those workers who answered yes, daily or yes, at least once per week to P.80.

Among 5211 respondents we identified 254 workers as mobbing victims. That means that $4.87 \%$ of the workers declared being mobbed at their workplaces.

There are two different studies we can carefully compare these results with. The first one is the Third European survey on working conditions 2000 finding that $5 \%$ of the workers in Spain are subjected to intimidation. There are important variations between countries, ranging from $4 \%$ in Portugal to $15 \%$ in Finland, but such differences probably reflect awareness of the issue rather than reality, because the questionnaire does not specify any definition or behavior for intimidation. The second work is the Barómetro Cisneros pointing out that more than $16 \%$ of the workers interviewed suffer from moral harassment or mobbing. This huge figure is obtained from a specific questionnaire about forms of harassment asked to workers from an industrial area near Madrid. As we will see, the Comunidad de Madrid is the region where we estimate the highest proportion of mobbing victims (10.7\%). However, such number is statistically smaller than the $16 \%$ estimated by the Barómetro Cisneros.

Next, we analyze how the percentage of mobbing victims we found in this study, (4.87\%), changes with personal and job characteristics. This information is contained in Table $1^{4}$ and can be interpreted as a first approximation to the potential factors which determine mobbing behaviors at the workplace. Standard errors for the corresponding percentages are in brackets. First, notice that a higher proportion of women $(5.55 \%)$ had experienced hostile behaviors at workplace compared to men $(4.47 \%)$. Being the household supporter does not show any difference in suffering from mobbing. We also find higher percentage of mobbing victims among those workers with more than three children and among foreign workers. However, as shown by the standard errors, the uncertainty in both cases is huge due to the small number of observations in these groups.

\footnotetext{
${ }^{3}$ Some authors, e.g. Lee (2002), argue that single incidents could be considered as mobbing. With this idea, when the victim suffers from physical violence, just once is enough for considering the worker as mobbed, because such experience is going to be easily repeated over again in the worker's mind.

${ }^{4} \mathrm{~A}$ detailed description of variables in Table 1 can be found in Appendix B.
} 
With respect to job characteristics, data suggest that mobbing is much more prevalent in the services sector $(6.13 \%)$, in particular, in social services $(7.70 \%)$ and in administration and bank (7\%). Relating to the size of the firm, mobbing is much more common activity in firms with more than 500 workers.

According to the data, working conditions have important effects on hostile behaviors. We found higher percentages of mobbing victims working during the weekend, earning a variable wage, and working more than 40 hours per week. Job training also seems to play an important role. Workers having been trained at the firm, (Job training and/or General Courses) seem to be less exposed to mobbing activities. Moreover, the percentage of mobbed workers are very different depending on the type of training.

As Leymann (1996) pointed out, apart from job characteristics and working conditions, work quality could be related to the process of mobbing. In order to explore this, we have summarized all information contained in the VENT (2003) on work quality in two variables: job quality and organizational factors. First, job quality is a variable reflecting a comfortable working environment. More specifically, it is a dummy variable taking value 1 when temperature and noise are adequate at the workplace. We have found big differences in the percentage of mobbed workers depending on the job quality. Second, the organizational factors variable includes information about the load of work and the degree of autonomy at the workplace. Only $2.83 \%$ of workers declaring positive organizational factors while working suffer from mobbing. However, this percentage raises dramatically to $9.07 \%$ when looking at workers with negative organizational factors while working.

Finally, it can be interesting to analyze the importance of geographical factors. Figure 1 shows wide variations in the proportion of mobbing victims by region. As we can see, with the exception of Asturias, where none worker has been identified as a mobbing victim, this figure varies from $0.85 \%$ in Navarra to $10.7 \%$ in Madrid.

To have a better understanding of the problem we concentrate next on analyzing the intensity and types of mobbing.

\subsection{Behaviors, intensity and types of mobbing}

As we said before, mobbing victims are identified as those workers suffering from at least one of the six behaviors contained in P.79 and P.80 and detailed in Table 2. The objective of this section is twofold. First, we study if there is a particular hostile behavior, among the previous six, which is commonly used by mobbers. And then, we focus on the intensity of mobbing, defined as the number of hostile behaviors suffered by the victim. 
Table 1: Prevalence of Mobbing (\%)

\begin{tabular}{|c|c|c|c|}
\hline Personal Characteristics & $(\%)$ & Working Conditions & \\
\hline Gender & & Wage & \\
\hline Female & $5.55(0.523)$ & Variable wage & $7.20(0.794)$ \\
\hline Male & $4.47(0.359)$ & Fixed wage & $4.29(0.317)$ \\
\hline H.S. & & Seniority & \\
\hline Yes & $4.86(0.385)$ & Less than 1 year & $4.41(1.033)$ \\
\hline No & $4.89(0.475)$ & $1-3$ years & $5.19(0.665)$ \\
\hline N. of children & & 3-10 years & $3.82(0.546)$ \\
\hline 0 & $4.70(0.396)$ & More than 10 years & $5.29(0.453)$ \\
\hline 1 & $5.42(0.645)$ & Job training & \\
\hline 2 & $4.50(0.675)$ & Yes & $3.78(0.281)$ \\
\hline 3 & $5.6(2.102))$ & No & $12.25(1.381)$ \\
\hline 4 & $8.33(6.703)$ & General courses & \\
\hline 5 & $16.1(12.89)$ & Yes & $4.31(0.369)$ \\
\hline Nationality & & No & $5.65(0.496)$ \\
\hline Spanish & $4.80(0.298)$ & Weekend & \\
\hline Foreigner & $11.6(4.206)$ & Yes & $7.13(0.536)$ \\
\hline Education & & No & $3.10(0.323)$ \\
\hline Elementary & $4.30(0.479)$ & Flexible & \\
\hline Secondary & $5.07(0.492)$ & Flexible & $3.55(0.529)$ \\
\hline College & $5.09(0.613)$ & Fixed & $5.25(0.354)$ \\
\hline & & Timetable & \\
\hline & & Split & $3.38(0.353)$ \\
\hline & & Non split & $5.27(0.526)$ \\
\hline & & Shifts & $9.59(1.129)$ \\
\hline & & Working hours & \\
\hline & & Up to 20 & $3.85(1.897)$ \\
\hline & & $21-40$ & $3.91(0.310)$ \\
\hline & & More than 40 & $8.42(0.827)$ \\
\hline Job Characteristics & & Work Quality & \\
\hline Sector & & Job quality & \\
\hline Industry & $2.47(0.492)$ & Yes & $3.64(0.394)$ \\
\hline Services & $6.13(0.395)$ & No & $6.34(0.473)$ \\
\hline Construction & $0.50(0.308)$ & & \\
\hline Size & & Organ. factors & \\
\hline Less than 10 & $3.37(0.657)$ & Positive & $2.83(0.603)$ \\
\hline $10-49$ & $3.35(0.492)$ & Negative & $9.07(0.949)$ \\
\hline $50-249$ & $2.90(0.518)$ & & \\
\hline $250-499$ & $3.36(0.945)$ & & \\
\hline More than 500 & $8.27(0.669)$ & & \\
\hline
\end{tabular}


Figure 1: Proportion of mobbing victims by CCAA

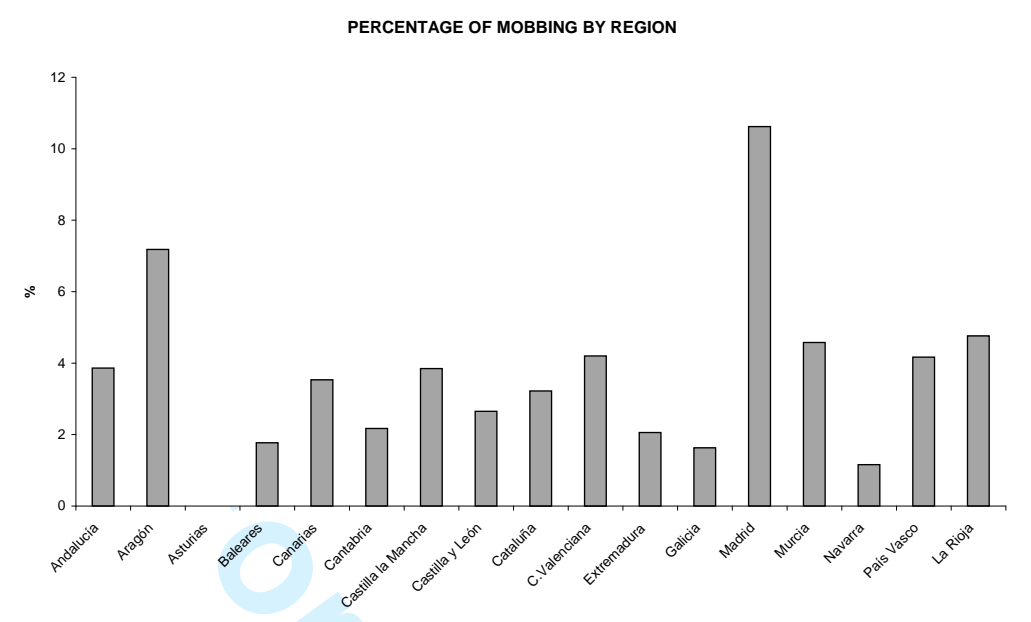

Table 2 shows the proportion of the identified mobbed workers who suffer from the behaviors used to identify mobbing. It is surprisingly large the percentage of mobbed workers (at least 40\%) who suffer from physical violence at their workplace. This violent behavior together with silencing, ignoring or isolating the victim are the activities which most mobbed workers suffer from. When looking at these numbers by gender, we can see that most mobbed male victims suffer from physical violence (more than 50\%) while most mobbed female victims suffer from being silenced, ignored, isolated (51.68\%). Therefore, it seems that male and female are mobbed in a different way. Notice also these gender differences in suffering from verbal and written threats and accidents. While just $2.88 \%$ of mobbed male workers suffer from this particular behavior, this number becomes $11.88 \%$ when looking at female victims. Note that the total sum of the percentages in Table 2 is greater than 100, reflecting that some workers suffer from more than one hostile behavior.

Intensity of mobbing can be thought in terms of the number of hostile behaviors suffered by the victim. The bigger the number of activities used to mobb, the higher the intensity of the mobbing process. Figure 2 plots the proportion of mobbing victims suffering from one, two, three and more than three mobbing activities. It is remarkable that most of the mobbing victims (71.1\%) suffer from just one of the mentioned hostile behaviors, which could be interpreted as being at the first stage of mobbing. As it is shown in the graph, most of the mobbed workers at their workplace are weakly mobbed while few of them are strongly mobbed. This is expected given that, as mentioned before, the workers we consider are still 
at their workplace. Most of the workers strongly mobbed are expected to quit the job, to change jobs or to be absent from work due to disability. Differences by gender are also found in the intensity of mobbing. The percentage of mobbed female victims suffering from more than one hostile behavior $(31.18 \%)$ is higher than the corresponding percentage of males (27.03\%), meaning that, in general, more female than male are strongly mobbed.

Figure 2: Proportion of mobbing victims by number of hostile behaviors suffered

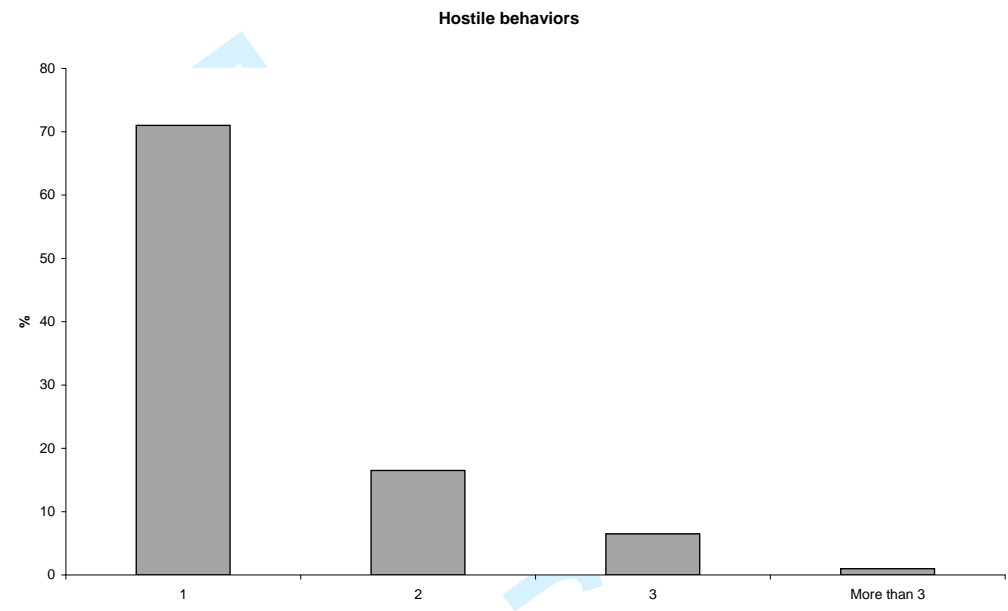

Finally, we can know from the survey who is the mobber, although there is no information about his/her characteristics. Using P.81. Who is/are the mobber/s: a superior, a subordinate, co-worker, we can identify who is mobbed by whom. Depending on who is the mobber, three types of mobbing can be considered: (i) Up-Down mobbing, when being mobbed by a superior, (ii) Horizontal mobbing, when being mobbed by a co-worker and (iii) Down-Up mobbing, when being mobbed by a subordinate. This could give us an idea about possible differences

Table 2: Mobbing activities. (\% among mobbing victims)

\begin{tabular}{l|c|c|c}
\hline Mobbing activities & Total & Female & Male \\
\hline Physical violence from people from the workplace & 11.50 & 12.93 & 10.47 \\
Physical violence from other people & 39.93 & 25.47 & 50.21 \\
Unwanted sexual attention & 7.3 & 8.50 & 6.52 \\
\hline Being silenced, ignored, isolated & 41.07 & 51.68 & 33.44 \\
Being humiliated, ridiculed, questioned & 27.98 & 32.25 & 24.78 \\
Suffering from verbal and written threats, accidents & 6.63 & 11.88 & 2.88 \\
\hline
\end{tabular}


Table 3: Proportion of mobbing victims by type of mobbing

\begin{tabular}{l|ccc} 
& Total & Female & Male \\
\hline Up-Down mobbing & 41.14 & 33 & 50 \\
Horizontal mobbing & 64.63 & 65.43 & 63.76 \\
Down-Up mobbing & 12.12 & 17.40 & 6.50 \\
\hline
\end{tabular}

among mobbed workers suffering from different types of mobbing.

Table 3 shows that, among mobbing victims, hostile behaviors occur mainly among co-workers: more than $64 \%$ of the mobbing victims declare being mobbed by co-workers. Up-Down mobbing has an incidence of $41.14 \%$, and the less usual case is being mobbed by a subordinate $(12.12 \%)$. Again, we have found gender differences. Although horizontal mobbing has similar prevalence in male and female victims, big differences are found for the other two types of mobbing. As we can see, the prevalence of Up-Down mobbing is higher in male than in female and the percentage of workers being mobbed by a subordinate is almost three times higher for females. Notice that, again, the percentages add up more than 100 which means that some workers are suffering from more than one type of mobbing.

\section{Determinants of Mobbing in Spain}

In this section we analyze which are the determinants of mobbing behaviors at workplace. To this aim, we focus on information about personal, firm and sector characteristics, labor conditions and work organization included in the VENT (2003). With this objective we consider the probit model given by

$$
\operatorname{Pr}(\text { Mobbed }=1 \mid X)=\Phi(X \beta)
$$

where the dummy variable Mobbed takes on the value 1 if the individual declared being mobbed and 0 otherwise and $\Phi(\cdot)$ is the standard cumulative normal probability distribution and $X$ is a vector containing exogenous explanatory variables. These variables, included in Table 1 , have been selected, among all variables in the VENT (2003), taking into account possible causes of hostile behavior given in the literature. Estimation results are shown in Table 4 (see the first two columns). They suggest that working conditions and job characteristics are more important at explaining mobbing than personal characteristics. Related to the latter, only gender and high-school are significant, that is, being a woman increases the probability of being mobbed and having high school education decreases this 
Table 4: Probit estimation for the dependent variable Mobbed

Total

Female

Male

\begin{tabular}{|c|c|c|c|c|c|c|}
\hline Variable & Coefficient & $\begin{array}{c}\text { Robust } \\
\text { Std. Error }\end{array}$ & Coefficient & $\begin{array}{c}\text { Robust } \\
\text { Std. Error }\end{array}$ & Coefficient & $\begin{array}{c}\text { Robust } \\
\text { Std. Error }\end{array}$ \\
\hline Const. & $-1.85^{* * *}$ & 0.190 & $-1.50^{* * *}$ & 0.341 & $-1.84^{* * *}$ & 0.231 \\
\hline \multicolumn{7}{|l|}{ Personal characteristics } \\
\hline Gender & $0.17^{*}$ & 0.095 & -- & -- & -- & -- \\
\hline Household Supporter & -0.03 & 0.089 & 0.05 & 0.135 & -0.07 & 0.112 \\
\hline N.Children & -0.02 & 0.044 & 0.04 & 0.081 & -0.04 & 0.049 \\
\hline Foreigner & 0.31 & 0.305 & 0.06 & 0.457 & 0.49 & 0.362 \\
\hline High-school & $-0.15^{*}$ & 0.088 & -0.09 & 0.157 & $-0.18^{*}$ & 0.109 \\
\hline College & -0.13 & 0.120 & -0.20 & 0.177 & -0.09 & 0.163 \\
\hline \multicolumn{7}{|l|}{ Job characteristics } \\
\hline Admin-Bank & $0.35^{* * *}$ & 0.113 & 0.10 & 0.174 & $0.51^{* * *}$ & 0.141 \\
\hline Soc-services & $0.43^{* * *}$ & 0.119 & $0.38^{* *}$ & 0.161 & $0.57^{* * *}$ & 0.160 \\
\hline Size 5 & $0.21^{* *}$ & 0.089 & 0.20 & 0.141 & $0.21^{*}$ & 0.112 \\
\hline \multicolumn{7}{|l|}{ Working Conditions } \\
\hline Vblewage & $0.19^{* *}$ & 0.088 & $0.28^{* *}$ & 0.140 & 0.16 & 0.111 \\
\hline Seniority & 0.00 & 0.044 & -0.03 & 0.073 & 0.01 & 0.056 \\
\hline Training & $-0.47^{* * *}$ & 0.102 & $-0.33^{*}$ & 0.182 & $-0.56^{* * *}$ & 0.125 \\
\hline Courses & -0.12 & 0.079 & 0.11 & 0.131 & -0.14 & 0.101 \\
\hline Weekend & $0.28^{* * *}$ & 0.084 & $0.24^{* * *}$ & 0.140 & $0.30^{* * *}$ & 0.104 \\
\hline Flexible & $-0.19^{*}$ & 0.105 & $-0.31^{*}$ & 0.172 & 0.16 & 0.140 \\
\hline Timetable & 0.07 & 0.055 & -0.07 & 0.092 & $0.13^{*}$ & 0.067 \\
\hline W. Hours $(>40)$ & $0.31^{* * *}$ & 0.091 & $0.29^{*}$ & 0.154 & $0.34^{* * *}$ & 0.113 \\
\hline J. quality & $-0.21^{* *}$ & 0.086 & $-0.30^{* *}$ & 0.123 & -0.18 & 0.113 \\
\hline C.Madrid & $0.33^{* * *}$ & 0.087 & $0.65^{* * *}$ & 0.134 & 0.08 & 0.119 \\
\hline Log pseudo-likelihood & -612.17783 & & -227.93599 & & -373.53912 & \\
\hline Pseudo $\mathrm{R}^{2}$ & 0.1097 & & 0.1236 & & 0.1201 & \\
\hline Number of Obs. & 4498 & & 1402 & & 3096 & \\
\hline
\end{tabular}

$*, * *, * * *$ significance at the $10 \%, 5 \%$ and $1 \%$ level, respectively.

probability (the reference category is elementary education). On the other hand, among job characteristics and working conditions only seniority, courses and timetable are not significant. It suggests that the number of years working for the same firm, general training and the type of timetable are not relevant when explaining being mobbed.

For all significant variables in the model, we have computed their marginal effects, which are shown in Table 5 (see the first two columns). We can see that Training, Soc-services, Admin-Bank, C. Madrid and W. Hours seem to be the ones with higher impact on the probability of suffering from mobbing. As it shown in the table, having received specific training at the firm decreases the probability of being mobbed almost 4\%. On the other hand, working for the social services, 
Table 5: Marginal effects for significant variables (\%)

Total

Female

Male

\begin{tabular}{|r|cc|cc|cc|}
\hline Variable & Coefficient & $\begin{array}{c}\text { Robust } \\
\text { Std. Error }\end{array}$ & Coefficient & $\begin{array}{c}\text { Robust } \\
\text { Std. Error }\end{array}$ & Coefficient & $\begin{array}{c}\text { Robust } \\
\text { Std. Error }\end{array}$ \\
\hline Personal characteristics & & & & & & \\
Gender & 1.05 & 0.62 & -- & -- & -- & -- \\
High-school & -0.82 & 0.48 & -- & -- & -0.86 & 0.50 \\
Job characteristics & & & & & & \\
Admin-Bank & 2.62 & 1.03 & -- & -- & 3.73 & 1.41 \\
Soc-services & 3.46 & 1.23 & 3.20 & 1.63 & 4.57 & 1.87 \\
Size5 & 1.40 & 0.66 & -- & -- & 1.19 & 0.71 \\
Working Conditions & & & & & & \\
Vblewage & 1.20 & 0.62 & 2.36 & 1.36 & -- & -- \\
Training & -3.91 & 1.16 & -2.91 & 2.02 & -4.30 & 1.40 \\
Weekend & 1.64 & 0.53 & 1.74 & 1.07 & 1.49 & 0.55 \\
Flexible & -0.97 & 0.48 & -1.82 & 0.88 & -- & -- \\
Timetable & -- & -- & -- & -- & 0.63 & 0.32 \\
W. Hours (> 40) & 2.16 & 0.74 & 2.50 & 1.57 & 2.00 & 0.79 \\
J. quality & -1.16 & 0.46 & -2.12 & 0.93 & -- & -- \\
C.Madrid & 2.33 & 0.73 & 6.54 & 1.78 & -- & -- \\
\hline
\end{tabular}

in the Administration/Bank sector, in the Comunidad de Madrid and working more than 40 hours per week increase in a significant amount $(3.46 \%, 2.62 \%$, $2.33 \%$ and $2.16 \%$ respectively) the probability of being a mobbing victim. With respect to variables affecting negatively such probability, we found that having a good job quality and a flexible timetable are the ones with a significant impact.

When we look at personal characteristics, being a woman increases significatively the probability of being mobbed, which is estimated $1.05 \%$ higher than for men. Moreover, it seems that human capital accumulation decreases $0.82 \%$ the probability of suffering from hostile behaviors.

Finally, although organizational factors seem to be very much related to mobbing, we have not included this variable in our estimation due to possible endogeneity problems. ${ }^{5}$

\footnotetext{
${ }^{5}$ We have also estimated alternative models. An ordered probit where the dependent variable reflects the intensity of mobbing gave us similar results adding the problems derived from having few observations in some categories. In order to explore possible differences at explaining hostile behaviors depending on the type of mobbing, we have also estimated three probit models, one per each type. However, the sample size for the Up-Down and Down-Up mobbing are not big enough to draw conclusive results. Consequently, the results are not shown in this paper but they are available from the authors upon request.
} 


\subsection{Gender differences}

Along this research we have noticed the existence of gender differences. First, we found a higher percentage of mobbing victims among women than among men, $5.55 \%$ versus $4.47 \%$. We have also found that this difference can increase when focussing on particular characteristics. For example, the percentage of males suffering from mobbing in Madrid is $8.30 \%$ while this percentage changes dramatically to $14.2 \%$ for females. On the other hand when looking at the AdministrationBank sector we found that $8.04 \%$ of the male workers are mobbed while just $5.90 \%$ of the female are mobbing victims in this sector.

Second, it seems that gender differences are also relevant among mobbed workers. As seen in subsection 2.1 male and female are mobbed differently, with different intensity and by a different type of mobbing. Finally, we have found that gender is a relevant variable at explaining the probability of being mobbed.

Therefore, it will be interesting to explore in more detail the differences by gender and to analyze if the variables explaining hostile behavior at workplace are the same and have the same impact depending on the victim's gender. To this aim, the previous probit model has been estimated separately for female and male. The results are shown in the last columns of Tables 4 and 5. They suggest there are indeed differences in the relevant variables. With respect to personal characteristics none of them is important at explaining mobbing for females while high-school is still significant for males with a similar negative impact than when looking at the whole sample. Related to job characteristics, only social services is significant for females with a similar positive impact. All job characteristics are relevant for males, although their impact on the probability of being mobbed changes slightly. Looking at working conditions, it is remarkable that Job quality and C. Madrid are not significant for males, while they are two of the most important variables at explaining mobbing among females. A female living in Madrid has a probability of being mobbed $6.54 \%$ higher than a female, with the same characteristics, living in another region. However, living in Madrid has no impact on this probability when dealing with males. Notice also that earning a variable wage and having a flexible timetable are significant variables for females but have no effect on the probability of being mobbed for males.

Finally, we have studied if women are still more likely to suffer from mobbing when the behavior Unwanted sexual attention is not considered in the definition of mobbing victims. The reason to do this is that such behavior is mostly related to women and we would like to test whether mobbers use mainly and only unwanted sexual behaviors when the victim is a woman. Hence, we have excluded from the mobbing victims group those workers declaring being subject 
to just one hostile behavior at workplace: unwanted sexual attention. There are 246 mobbing victims with this definition, which means $4.72 \%$ of the total sample. We have estimated the same probit model as before finding similar results ${ }^{6}$ with the exception of the significance of the variable gender. This variable is not significant anymore meaning that gender is not relevant at explaining mobbing behaviors. This result could suggest that gender differences found in the process of mobbing are mostly driven by hostile activities related to sexual behaviors. However, this should be taken carefully given that there are other aspects such as discrimination and/or labor market segregation which we are not taking into account.

\section{Conclusions}

In this paper we have analyzed the problem of mobbing in Spain during 2003. We found that around $5 \%$ of workers who are at their workplace suffer from hostile behaviors. Significant differences in the percentage of mobbed workers are found by region, sectors and size of the firms, being Madrid, the services sector and firms with more than 500 workers where we find the highest mobbing rates. With respect to the intensity of the mobbing process, we found that most of the victims suffer from just one hostile behavior, specially male. Moreover, horizontal mobbing is the most common one with similar prevalence in males and females.

A probit model was fitted to the data and the results suggest that working conditions and job characteristics are more important at explaining mobbing than personal characteristics. More precisely, working in the services sector, in large firms, earning a variable wage, working during the weekends, more than 40 hours per week and in Madrid are factors with a positive impact on the probability of being mobbed. On the other hand, having been trained at the firm, having a flexible timetable and good job quality have a negative impact on such probability.

Finally, we found that women are more likely to be mobbed than men and also there are significant differences in the variables explaining mobbing depending on the victim's gender. Personal and job characteristics are more relevant for males while working conditions are more relevant for females.

Measuring the effects of mobbing on victim's health, disability, and productivity loss are other important factors to explore which are in our research agenda.

\footnotetext{
${ }^{6}$ The estimation results are avalaible upon request.
} 


\section{References}

[1] Cowie, H., Jennifer, D., Neto, C., Carlos Angllo, J., Del Barrio, C and Ananiadou K. (2000), Comparing the nature of workplace bullying in two European countries: Portugal and UK, in M. Sheehan, S. Ramsay and J. Patrick (Eds) Transcending Boundaries: Integrating people, Processes and Systems, Conference Proceedings, Brisbane, Queensland.

[2] Hirigoyen, M-F. El acoso moral en el trabajo. Distinguir lo verdadero de lo falso. Barcelona, Ed Paidós 2001.

[3] Hoel, H., Sparks, K. and L. Cooper, (2001), "The cost of violence/stress at work and the benefits of a violence/stress-free working environment". Report Commissioned by de ILO Geneva.

[4] Hubert, A.B., Furda, J. and H. Steensma (2001), "Mobbing: Systematic harassment in organizations", Gedrage Organisatie, 14, 378-396.

[5] Lee, D. (2002), "Gendered worplace bullying in the restructured UK Civil Service" Personnel Review, 31, 205-227.

[6] Lewis, M.A. (2006), "Nurse Bullying: organizational considerations in the maintenance and perpetration of health care bullying cultures" Journal of Nursing Management, 14, 52-58.

[7] Leymann, H. Mobbing. La persecution au travail. Paris, Ed Seuil, 1996.

[8] Pastrana, J.I. (2002), " Cúanto cuesta el mobbing en España? " Lan Harremanak/7, 171-181.

[9] Piñuel y Zabala, I. and A. Oñate (2002), "La incidencia del mobbing o acosos psicológico en el trabajo en Espña: resultaos del barómetro Cisneros sobre violencia en el entorno laboral", Lan Harremanak/7, 35-62.

[10] Vega, G. and Comer, D. (2005), "Sticks and Stones may break your bones but words can break your spirit: Bullying in the workplace" Journal of Business Ethics, 58, 101-109. 


\section{A Leymann Inventory of Psychological Terror- ization: LIPT}

(A) Activities on the possibilities of the mobbed person or mobbing victim to communicate adequately:

1. The aggressor or mobber gives the victim no possibility to communicate.

2. The victim is silenced or continuously interrupted.

3. Colleagues prevent the victim to communicate.

4. Colleagues scream and shout at the victim.

5. The victim suffers verbal attacks regarding work assignments.

6. The victim suffers verbal attacks regarding her/his personal life.

7. The victim is terrorized by means of phone calls.

8. The victim suffers verbal threats.

9. The victim suffers written threats.

10. People at work refuse to make any contact with the victim.

11. The victim's presence is ignored.

(B) Activities on the possibilities of the victim to maintain social contacts:

12. The aggressor does not talk to the victim.

13. The victim is forbidden to talk to the aggressor.

14. The victim is isolated in a room far away from others.

15. Colleagues are forbidden to talk to the victim.

16. The physical presence of the victim is denied.

(C) Activities on the possibilities of the victim to maintain his/her personal reputation:

17. Slanders and lies about the victim are used at work.

18. Gossiping about the victim.

19. The victim is ridiculed.

20. The victim is said to have a mental illness.

21. The aggressor tries the victim to go through psychiatric exams. 
22. The victim is supposed to be ill.

23. The victim's voice, gestures, way of moving are imitated.

24. The victim suffers verbal attacks regarding her/his political and religious beliefs.

25. People at work make fun about the victim's personal life.

26. People at work make fun about the ethnic heritage or nationality of the victim.

27. The victim is forced to do humiliating jobs.

28. The victim is controlled and his/her job performance is tracked for those with bad intentions.

29. Victim's decisions are questioned.

30. The victim is reviled using obscene or degrading terms.

31. The victim is sexually harassed.

(D) Activities on the occupational situation of the victim:

32. The victim is not given any work assignments at all.

33. The victim is deprived of any activity when being at work.

34. The victim is given meaningless work assignments.

35. The victim is given work assignments far below her/his capacity.

36. The victim is continuously given new work assignments.

37. The victim is given humiliating work assignments.

38. The victim is given difficult work assignments far above her/his capacity.

(E) Activities on the physical health of the victim:

39. The victim is given dangerous work assignments.

40. The victim is physically threaten.

41. The victim is physically attacked as a threat.

42. The victim is physically attacked with serious consequences for his/her health.

43. The victim is deliberately forced to spend big sums of money.

44. Accidents are caused in the victim's workplace or home.

45. The victim is sexually attacked. 


\section{B Variables definition}

- Gender: Dummy variable taking the value 1 if female and 0 if male.

- Age: Age of the worker in years.

- Children: Discrete variable taking values from 0 to 5 which indicates the number of children younger than 18 who live with the worker. The value 5 refers to 5 or more.

- Foreigner: Dummy variable taking the value 1 if foreigner and 0 if from Spain.

- Elementary: Dummy variable taking the value 1 if worker's education is elementary school and 0 otherwise.

- High-school: Dummy variable taking the value 1 if worker's education is high school and 0 otherwise.

- College: Dummy variable taking the value 1 if worker's education is college and 0 otherwise.

- Household supporter (H.S.): Dummy variable taking the value 1 if worker's salary is the largest of the household and 0 otherwise.

- Tenure: Dummy variable taking the value 1 if having a permanent job and 0 otherwise.

- Fulltime: Dummy variable taking the value 1 if it is a fulltime job and 0 otherwise.

- Vblewage: Dummy variable taking the value 1 if worker's wage is not fixed and 0 otherwise.

- Team: Dummy variable taking the value 1 if the individual works with others and 0 otherwise.

- Experience: Number of years the individual has been working for the actual firm.

- Training: Dummy variable taking the value 1 if being trained for the job at the organization and 0 otherwise.

- Workplace: Dummy variable taking the value 1 if working at a closed space(office, room) and 0 otherwise. 
- Temperature: Dummy variable taking the value 1 if the temperature at the workplace is comfortable and 0 otherwise.

- Noise: Dummy variable taking the value 1 if working at a noisy workplace and 0 otherwise.

- Sitting: Dummy variable taking the value 1 if the position while working is sitting and 0 otherwise.

- Hours: Number of hours the individual works per week.

- Timetable: Discrete variable taking values from 1 to 3 . The value 1 refers to split timetable, 2 refers to non split timetable and 3 refers to shifts.

- Weekend: Dummy variable taking the value 1 if working during the weekends and 0 otherwise.

- Flexible: Dummy variable taking the value 1 if flexible timetable and 0 otherwise.

- Courses: Dummy variable taking the value 1 if having received formation (courses, talks, ...) organized by the actual firm and 0 otherwise.

- Size: Discrete variable taking values from 1 to 5 increasing with the number of workers in the firm.

- Services: Dummy variable taking the value 1 if the individual works in the services sector and 0 otherwise.

- Admin-Bank: Dummy variable taking the value 1 if the individual works in Administration/Banks and 0 otherwise.

- Retail-Hosp: Dummy variable taking the value 1 if the individual works in Retails/Hospitality and 0 otherwise.

- Soc-services: Dummy variable taking the value 1 if the individual works in Social Services and 0 otherwise.

- Muchwork: Dummy variable taking the value 1 if the workload has been too much during the last three months and 0 otherwise.

- Lesswork: Dummy variable taking the value 1 if the workload has been too few during the last three months and 0 otherwise. 
- Responsibility: Discrete variable taking values from 1 to 3 increasing with the job responsibility. The value 1 refers to no responsibility, 2 refers to few responsibility and 3 refers to much responsibility.

- Mobbed: Dummy variable taking the value 1 if mobbed and 0 otherwise. 